\title{
Zmiany sieci hotelowej w aglomeracji krakowskiej po II wojnie światowej
}

Infrastruktura hotelowa należy do ważniejszych składników bazy ekonomicznej wiodących aglomeracji miejskich. Umożliwia ona rozwój różnego typu funkcji turystycznych, w tym między innymi turystyki biznesowej.

Kraków w okresie powojennym należał i do dziś należy do wiodących centrów krajowych i traktowany jest jako kulturalna stolica kraju. Z pewnością funkcje turystyczne miasta należy coraz bardziej rozwijać, dążąc w ten sposób do podniesienia jego atrakcyjności w przestrzeni europejskiej i światowej. Ważną przesłanką w realizacji założonych wyżej celów jest jakość bazy hotelowej, jej organizacja, formy zarządzania oraz konkurencyjność cenowa.

W okresie od 1945 do 2009 roku zmieniały się uwarunkowania rozwoju gospodarki, które wpływały na zmiany infrastruktury i jakości bazy hotelarskiej. Związane jest to w głównym stopniu ze zmianami systemu gospodarowania, w którym nastąpiły zmiany własnościowe hoteli oraz pojawiły się możliwości rozbudowy i modernizacji infrastruktury.

Obecny kształt sieci hotelarskiej aglomeracji krakowskiej jest efektem wielu przeobrażeń zarówno natury politycznej, jak i społecznej, gospodarczej czy kulturowej. Trwający przez ponad 60 lat proces to lata stagnacji (lata powojenne), czas niewielkiego ożywienia okresu gospodarki centralnie sterowanej (lata 60. i 70.) aż po okres dynamicznego wzrostu w okresie ostatniego dwudziestolecia.

\section{SiEĆ HOTELOWA A PRZYJAZDY DO KRAKOWA}

Rozwój sieci hotelowej związany jest z liczbą przyjazdów turystycznych i popytem na usługi tego typu. Jednocześnie wysokiej jakości baza hotelowa kreuje tenże popyt i wpływa na decyzje o przyjeździe do miasta.

Po integracji Polski ze strukturami Unii Europejskiej oraz dołączeniu do grupy Układu z Schengen nastapił wzrost liczby przyjazdów do Krakowa. Wyjątkowo istotna jest wiedza dotycząca charakteru tego zjawiska w ujęciu ilościowym i jakościowym. Pozwala ona śledzić trendy i elastycznie reagować na zmiany zachodzące na tym rynku.

Badaniem turystyki przyjazdowej do Krakowa zajmuje się Małopolska Organizacja Turystyczna (MOT) i Urząd Statystyczny. MOT opracowuje rozbudowane roczne raporty 
na zlecenie Urzędu Miasta Krakowa, natomiast dane Urzędu Statystycznego pochodzą z przygotowywanych przez gestorów bazy hotelarskiej raportów miesięcznych.

Dzięki badaniom widać postępujący od 2001 roku wzrost udzielonych noclegów. Rok 2007 okazał się rekordowy pod tym względem; w roku 2008 obserwujemy już spadek liczby udzielonych noclegów. Tendencja ta utrzymała się również w roku 2009.

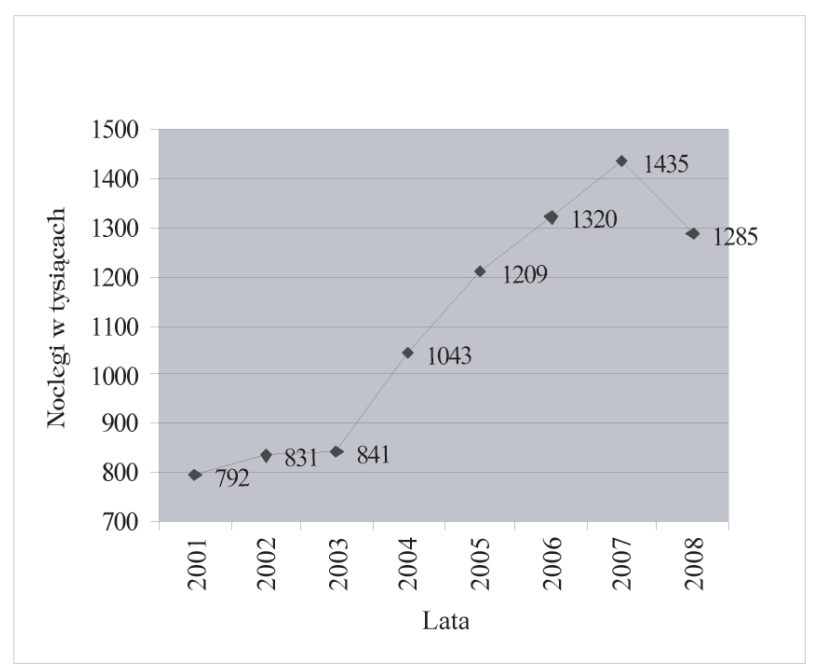

Ryc. 1. Liczba noclegów udzielonych w Krakowie w latach 2001-2008

Źródło: Ruch turystyczny w Krakowie... 2008

\section{HOTEL JAKO OBIEKT HOTELARSKI}

Na bazę noclegową składają się obiekty hotelarskie różnego typu - od hoteli i moteli poprzez pensjonaty, domy wycieczkowe, schroniska, po pola biwakowe. Zgodnie z dostępnymi danymi, sieć hoteli w Krakowie jest najdynamiczniej rozwijającą się częścią tej bazy. W chwili obecnej na 149 obiektów wszystkich kategorii zgłoszonych do ewidencji w Krakowie, 135 to hotele.

Hotelem nazywany obiekt, posiadający co najmniej 10 pokoi, w tym większość miejsc w pokojach jedno- i dwuosobowych, świadczący szeroki zakres usług związanych z pobytem klientów ${ }^{1}$. Każdy obiekt, by móc w zgodzie z prawem używać nazwy hotel, musi poddać się procesowi tzw. kategoryzacji, czyli zaszeregowania (Gaworecki 2007). Dla hoteli wyróżnia się pięć kategorii oznaczonych gwiazdkami.

Zaszeregowania obiektów hotelarskich do poszczególnych rodzajów dokonuje, kategorię nadaje oraz prowadzi ich ewidencję marszałek województwa właściwy ze względu na miejsce położenia obiektu hotelarskiego. Wymagania kategoryzacyjne wskazują na materialną i niematerialną część jakości usługi świadczonej w hotelach².

\footnotetext{
1 Ustawa o usługach turystycznych z 29 sierpnia 1997 r.

2 Rozporządzenie Ministra Gospodarki i Pracy z 19 sierpnia 2004 r.
} 
Oprócz określanego przepisami standardu hotele mogą pełnić wiele różnych funkcji zależnych od ich położenia i potrzeb gości. Wyróżnia się hotele biznesowe, rezydencjalne, uzdrowiskowe, tranzytowe, kongresowe i inne. W Krakowie najczęściej spotykamy hotele miejskie, charakteryzujące się stosunkowo krótkimi pobytami gości (ok. 3 noce).

\section{ZMIANY SIECI HOTELOWEJ W OKRESIE 1945-2009}

\section{Okres powojenny 1945-1960}

Krakowskie hotele, służące podczas wojny za siedziby okupanta, a następnie często złupione i zniszczone przez wyzwoleńczą Armię Czerwoną nie wznowiły po wojnie swojej działalności w dotychczasowym kształcie. Niepewna przyszłość, brak możliwości finansowania, nacjonalizacja nieruchomości nie tworzyły warunków koniecznych do odrodzenia się samodzielnie funkcjonujących przedsiębiorstw hotelarskich. Okres powojenny okazał się najtrudniejszy dla branży. Gestorami obiektów hotelarskich stało się państwo, spółdzielnie, miasto Kraków, organizacje społeczne i tylko częściowo prywatni właściciele.

Realizowana polityka centralnego sterowania z wdrażanym programem tzw. hotelarstwa socjalnego nie pozostawiała miejsca na funkcjonowanie prywatnych hoteli oferujących wysoki poziom usług. Powołane do życia organizacje, jak: Juventur, Gromada, Almatur, FWP i inne realizowały socjalne programy powiązane z turystyką. Jakość ich usług była jednak niska, a mienie powierzone tym organizacjom, źle zarządzane, popadało w ruinę.

Krakowski rynek turystyki przyjazdowej aż do lat 90. w całości należał do dwóch podmiotów:

1. Orbisu, który zarządzał siecią pensjonatów, wagonami sypialnymi i restauracyjnymi w pociągach, a po roku 1950 również siecią hoteli (w Krakowie np. Hotel Francuski). Miały one zostać dostosowane do obsługi gości z zagranicy. Obok wcześniej wymienionych zadań, Orbis organizował różnego rodzaju zjazdy, spotkania dla pracowników administracji i organizował transport osobowy.

2. Krakowskiego Przedsiębiorstwa Turystycznego Wawel Tourist, zarządzającego kilkoma krakowskimi hotelami (Polonia, Europejski), które nie remontowane popadały w ruinę. Dopiero po roku 1990 wróciły w ręce prawowitych właścicieli.

W opisywanym okresie w Krakowie funkcjonowało zaledwie kilka hoteli. Ich losy były podobne, co zostało opisane poniżej.

Funkcjonujący przed wojną Hotel Saski zaszczycany był obecnością wielu sławnych osobistości, takich jak Ignacy Paderewski, Józef Hofmann, Artur Rubinstein czy Stefan Żeromski, należał do Polskiego Towarzystwa Handlowego S.A. W latach 70. obiekt został przejęty przez Związek Socjalistycznej Młodzieży Polskiej „Juventur” i dopiero w roku 1991 wrócił w ręce prawowitych właścicieli, potomków członków $\mathrm{PTH}^{3}$.

Słynący dziś ze wspaniałej kuchni i wyśmienitej kolekcji win Hotel pod Różq w czasie II wojny światowej zajmowany był przez urzędników i armię niemiecką. Po wojnie zarządzany był przez krewnych właścicielki.

Z funkcjonującymi w nim mieszkaniami, nie przypominał dawnego hotelu. W 1950 roku, wraz z wszystkimi hotelami krakowskimi, przeszedł pod zarząd państwowy. Wtedy

\footnotetext{
${ }^{3}$ Opracowanie własne na podstawie danych dostępnych na stronie hotelu www.hotelsaski.com.pl.
} 
pełnił funkcję domu wycieczkowego, oferując nocleg na piętrowych łóżkach. Zamknięcie hotelu na 10 lat w 1970 roku pozwoliło na przeprowadzenie gruntownego remontu. W lipcu 1988 roku w piwnicach rozpoczęła działalność słynna na cały kraj galeria artystyczna. W hotelu funkcjonowało pierwsze w Polsce kasyno gry. Od 1994 roku hotel został własnością znanej krakowskiej rodziny hotelarzy. Po remoncie w 2005 r. stał się jednym z najlepszych hoteli w Polsce, goszczącym wielu znakomitych gości ${ }^{4}$.

Historia hotelu Grand sięga roku 1886. Tuż przed wybuchem wojny stał się miejscem opisywanym w doskonałej powieści Henryka Worcella Zaklęte rewiry. Lata powojenne to zmierzch świetności Grand Hotelu. Rozpoczął się wówczas okres naznaczony stagnacją, postępującą dewastacją oraz „remontami”, które przyczyniły się tylko do dalszego upadku obiektu. W 1960 roku obiekt został upaństwowiony, co przyspieszyło jego upadek. Dopiero w roku 1990 hotel przejęła prywatna spółka. Podjęła ona działania, które doprowadziły do przywrócenia dawnej świetności tego obiektu ${ }^{5}$.

\section{Lata 60.-90.}

Na lata 1960-1980 przypada okres dynamicznego rozwoju przedsiębiorstwa Orbis - lidera branży. W tym okresie firma wybudowała w całej Polsce 34 nowe hotele. Większa otwartość na świat wymuszała budowę obiektów o wysokim standardzie, mogących zaoferować odpowiedni poziom usług. W tym okresie w Krakowie zrealizowano trzy duże inwestycje hotelowe.

Hotel Cracovia, budowany w latach 1961-1964, pozostaje do dziś największym hotelem w mieście (318 pokoi). Długość budynku wynosi 150 metrów. Hotel posiada doskonałą lokalizację. Oprócz restauracji i popularnej niegdyś kawiarni mieści również kasyno.

W połowie lat 70. XX wieku wybudowano najnowocześniejszy wówczas w Polsce hotel Holiday Inn. Znajdujący się przy ulicy Armii Krajowej obiekt posiada 304 pokoje, restaurację i zaplecze konferencyjne. W związku z nieprzedłużeniem umowy licencyjnej, hotel zmienił nazwę na Continental, a następnie dołączył do łańcucha Novotel, marki należącej do Accor - nowego właściciela spółki Orbis. Hotel funkcjonuje do dziś.

Położony nad Wisłą, imponujący hotel Forum, budowano w latach 1978-1988. Powstał na podstawie projektu Janusza Ingardena. W latach swojego funkcjonowania oferował gościom 278 klimatyzowanych pokoi, 2 restauracje, dwupoziomowy parking, basen, saunę, solarium, studio odnowy biologicznej, korty tenisowe. W obiekcie znajdowały się również sklepy, w tym Pewex. Wielu gości hotelu pamięta ogromne sale konferencyjne (dla 600 osób), w których odbywało się wiele imprez i spotkań. Zastosowane w hotelu nowoczesne rozwiązania techniczne były na owe czasy rewolucyjne. W 2002 roku hotel został zamknięty, a następnie sprzedany. Nie wiadomo, czy zostanie w nim wznowiona działalność hotelarska.

\section{Okres po roku 1989}

Wskutek zmian politycznych w 1989 roku w Polsce tworzyły się zręby systemu gospodarczego o orientacji rynkowej. Stabilizująca się sytuacja gospodarcza oraz ułatwienia paszportowe, celne i wizowe zwiększały atrakcyjność Polski jako celu wyjazdów. Jednocześnie postępująca demonopolizacja i przekształcenia własnościowe stworzyły warunki do odbudowy sektora prywatnego oraz prywatyzacji przedsiębiorstw państwowych. Dostęp do kapitału dla prywatnych inwestorów i jego optymalne wykorzystanie zaowocowało pojawieniem się na rynku samodzielnie działających przedsiębiorstw hotelarskich.

\footnotetext{
${ }^{4}$ Strona internetowa firm grupy „Likus hotele i restauracje”, www.hotel.com.pl.

${ }^{5}$ Na podstawie danych dostępnych na www.grand.pl.
} 
Występujący jednocześnie postęp w zakresie infrastruktury transportowej, środków transportu oraz technologii związanej z przepływem informacji wpłynął na podwyższenie atrakcyjności Krakowa.

Wymienione wyżej czynniki spowodowały zainteresowanie inwestycjami hotelowymi w Polsce. Na rynku pojawiły się międzynarodowe marki, a hotele działające w ich strukturach korzystały z doświadczeń i nowoczesnych narzędzi liderów branży.

Funkcjonujące aktualnie w Krakowie hotele można podzielić, stosując różne kryteria. Przy podziale ze względu na przynależność do międzynarodowych łańcuchów można wyróżnić:

- hotele sieciowe,

- hotele nie należące do sieci.

Hotele sieciowe posługują się rozpoznawalnym znakiem firmowym i gwarantują standard usługi. Już w latach 50. na świecie dostrzeżono korzyści wynikające ze standaryzacji w działalności hotelarskiej. Zjawisko to przejawiało się w budowaniu podobnych obiektów z ujednoliconym wyposażeniem, zakresem usług i wspólnym systemem rezerwacji. Tak zorganizowany zespół hoteli nazywany jest łańcuchem hotelowym. Niespotykaną dynamikę rozwoju łańcuchów hotelowych zapewniło udzielanie licencji na prowadzenie hotelu, pod tą samą marką przez różnych właścicieli. System ten oparty jest na ścisłej i ciągłej współpracy pomiędzy prawnie i finansowo odrębnymi i niezależnymi przedsiębiorstwami - franczyzodawcą i jego indywidualnymi franczyzobiorcami. Franchising zakłada też przepływ „know-how” od franczyzodawcy do franczyzobiorcy przez cały czas obowiązywania umowy franczyzowej.

W przypadku umów o zarządzanie firma oferuje franczyzobiorcy pomoc w zatrudnieniu profesjonalnych kadr, dodatkowe narzędzia optymalizacji przychodów, a także dostęp do kredytów lub finansowanie inwestycji. W Krakowie na wspomnianych wcześniej zasadach funkcjonuje wiele hoteli sieciowych (ryc. 2).

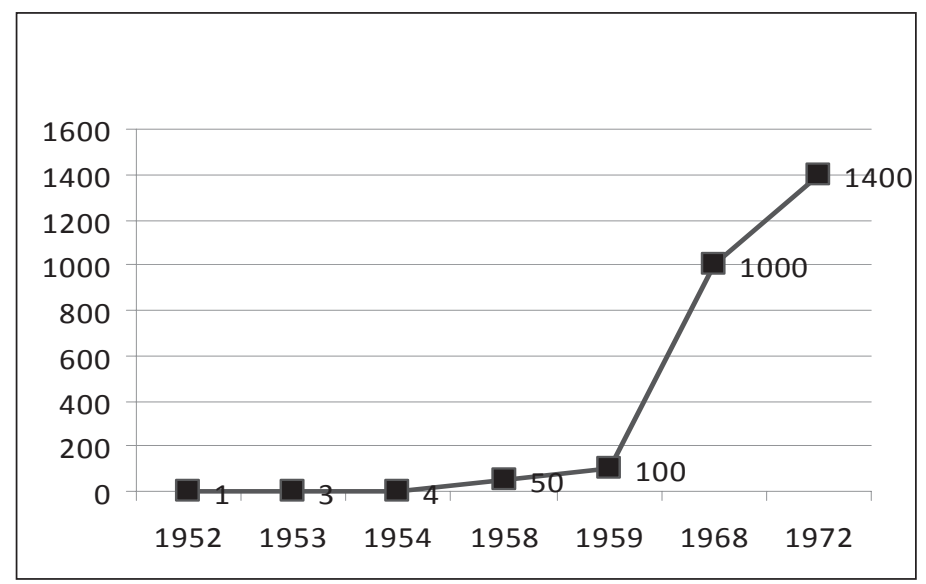

Ryc. 2. Wzrost liczby hoteli łańcucha Holiday Inn na świecie dzięki wprowadzeniu franczyzy w hotelarstwie

Źródło: Opracowanie własne na podstawie danych o historii korporacji Intercontinental Hotels Group dostępnych w materiałach informacyjnych firmy 
Wraz z rozwojem rynku i zróżnicowanymi wymaganiami gości pojawiły się systemy hotelowe, nazywane również grupami hotelowymi. Skupiając kilka łańcuchów hotelowych, oferują usługi o zróżnicowanym standardzie dla różnych segmentów gości.

Przykłady systemów hotelowych obecnych w Krakowie zawarto w tabeli 1.

Tab. 1. Hotele działające w Krakowie na zasadzie licencji w 2009 roku

\begin{tabular}{|l|l|l|}
\hline \multicolumn{1}{|c|}{ System } & \multicolumn{1}{|c|}{ Łańcuch } & \multicolumn{1}{c|}{ Lokalizacja } \\
\hline Best Western International & Best Western Premiere & ul. Opolska 14a \\
\hline $\begin{array}{l}\text { Starwood Hotels and Resorts } \\
\text { Worldwide }\end{array}$ & Sheraton & ul. Powiśle 7 \\
\hline Rezidor Hotel Group & Radison Blu, Park Inn & $\begin{array}{l}\text { ul. Straszewskiego 17, } \\
\text { ul. Monte Cassino 2 }\end{array}$ \\
\hline $\begin{array}{l}\text { Inter Continental Hotels } \\
\text { Group (IHG) }\end{array}$ & $\begin{array}{l}\text { Holiday Inn, Express by } \\
\text { Holiday Inn }\end{array}$ & ul. Wielopole 4, ul. Opolska 14 \\
\hline Hilton Hotels Corporation & Hilton Garden Inn & ul. Marii Konopnickiej (w budowie) \\
\hline
\end{tabular}

Źródło: Opracowanie własne na podstawie danych z ewidencji obiektów hotelarskich. Internetowy serwis informacyjny Ministerstwa Sportu i Turystyki

Większą część sieci hotelowej tworzą średnie i małe hotele, nienależące do łańcuchów i sieci. Te samodzielnie działające przedsiębiorstwa korzystają z nowoczesnych narzędzi dystrybucji i sprzedaży, co pozwala im na skuteczne konkurowanie z liderami branży ${ }^{6}$.

Atutem małych hoteli jest ich specyficzny charakter, atmosfera i indywidualne podejście do gościa - co jest trudne do osiagnięcia w dużych hotelach sieciowych. Dużą zaletą jest również ich lokalizacja - często w zaadaptowanych zabytkowych kamienicach położonych w centrum miasta. Położenie tych obiektów, często występujących w grupach, odpowiada modelowi koncentrycznego użytkowania ziemi w mieście (Kowalczyk 2001). Wzrastająca wysokość renty gruntowej w obszarach recepcji turystycznej miasta wymusza zwiększenie funkcji usługowo-handlowych, w tym hotelarskich, co jest widoczne w Krakowie w obrębie Plant.

\section{W SPÓŁCZESNA SIEĆ HOTELOWA W KRAKOWIE}

W przypadku dużej ilości przyjazdów następuje stopniowo specjalizacja usług - będąca odpowiedzią na różne potrzeby i możliwości finansowe turystów. Istniejąca w przestrzeni miasta baza noclegowa dostosowana jest do oczekiwań gości. Współcześnie w Krakowie najliczniej reprezentowana jest grupa hoteli miejskich, nastawionych na krótkie kilkudniowe pobyty. Specyficzne potrzeby gości zaspokajają hotele tranzytowe, kongresowe i apartamentowe, które stopniowo pojawiają się na rynku.

Aktualnie w Krakowie znajduje się 8 hoteli pięciogwiazdkowych, 20 hoteli czterogwiazdkowych. Najliczniej reprezentowana jest grupa hoteli trzygwiazdkowych, których jest w Krakowie 76. Hotele niższej kategorii, dwugwiazdkowe i jednogwiazdkowe, stanowią odpowiednio 23 i 6 obiektów.

\footnotetext{
${ }^{6}$ Na przykład HRS, EXPEDIA i inne systemy rezerwacji dostępne dla wszystkich hotelarzy.
} 


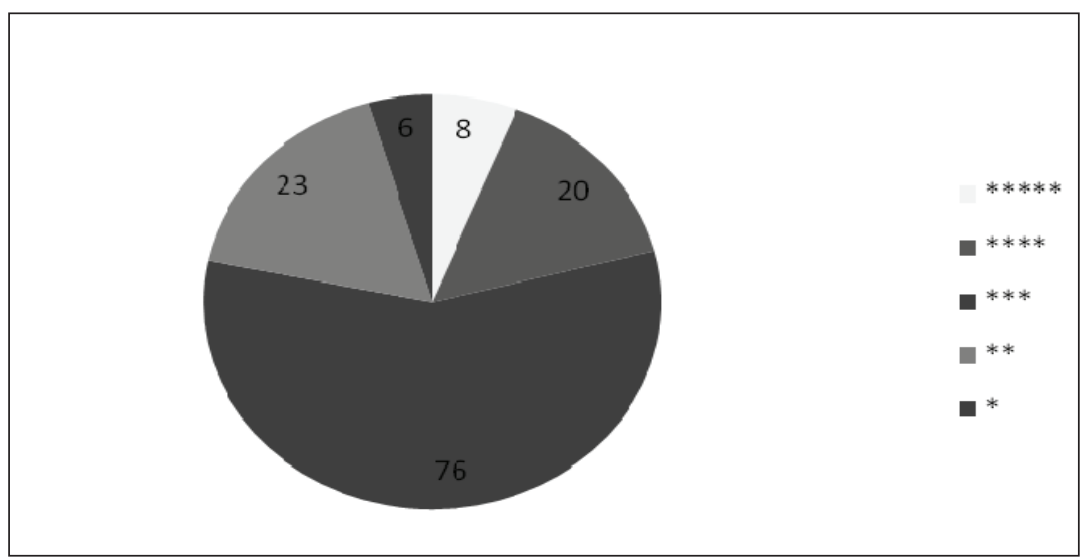

Ryc. 3. Liczba hoteli w Krakowie w roku 2009 w podziale na kategorie

Źródło: Opracowanie własne na podstawie danych z ewidencji obiektów hotelarskich. Internetowy serwis informacyjny Ministerstwa Sportu i Turystyki

Liczba hoteli poszczególnych kategorii jest zależna od wielu czynników. W przypadku hoteli najwyższej kategorii warto zauważyć, iż są one prawie wszystkie zlokalizowane w centrum miasta. Dodatkowo zdecydowana większość obiektów pięciogwiazdkowych to hotele sieciowe. Na uwagę zasługuje fakt, iż reprezentują one $6 \%$ wszystkich obiektów w mieście, natomiast posiadają $12 \%$ wszystkich pokoi.

Standard czterogwiazdkowy reprezentuje 20 obiektów, w większości położonych w dzielnicy Stare Miasto. Stanowi to $15 \%$ hoteli miasta i $23 \%$ wszystkich pokoi. Powyższe dane wskazują na fakt, iż hotele najwyższych kategorii to w większości obiekty duże (powyżej 100 pokoi).

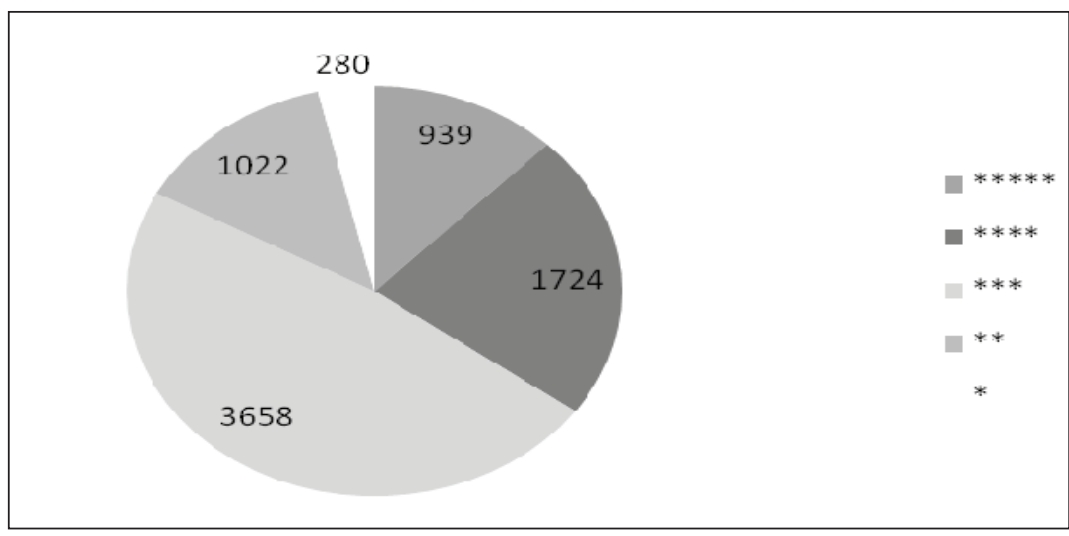

Ryc. 4. Liczba pokoi w poszczególnych kategoriach hoteli w roku 2009 w Krakowie

Źródło: Opracowanie własne na podstawie danych z ewidencji obiektów hotelarskich. Internetowy serwis informacyjny Ministerstwa Sportu i Turystyki 
Na uwage zasługuje najliczniej reprezentowana grupa hoteli średniego standardu. Trudne do spełnienia w zabytkowych nieruchomościach warunki dla uzyskania czterech gwiazdek są możliwe w przypadku standardu trzygwiazdkowego. Nie najwyższy standard będzie rekompensowała dobra lokalizacja.

Grupa 76 hoteli tej kategorii reprezentuje 57\% wszystkich obiektów, oferując 48\% wszystkich pokoi. Świadczy to o średniej wielkości tych hoteli (przeciętnie 48 pokoi).

Hotele budżetowe, posiadające 2 i 1 gwiazdkę, położone są w większości poza centrum miasta. Kluczowym kryterium wyboru tych obiektów przez turystów będzie niska cena. Ich lokalizacja nie będzie najważniejsza. Hotele dwugwiazdkowe stanowią 17\% wszystkich obiektów, oferując 13\% dostępnych pokoi. Najniższy standard jednogwiazdkowy to 5\% hoteli i $4 \%$ pokoi w mieście.

Współczesna sieć hotelowa w Krakowie charakteryzuje się nierównomiernym rozmieszczeniem. Najbardziej atrakcyjne dla tego typu obiektów jest Stare Miasto, gdzie zlokalizowanych jest 57 hoteli, w tym prawie wszystkie hotele najwyższej kategorii.

Na dalszych pozycjach znajdują się Dębniki, Łagiewniki i Podgórze - po 9 obiektów. Najmniej atrakcyjnymi dzielnicami są: Mistrzejowice, Wzgórza Krzesławickie i Podgórze Duchackie.

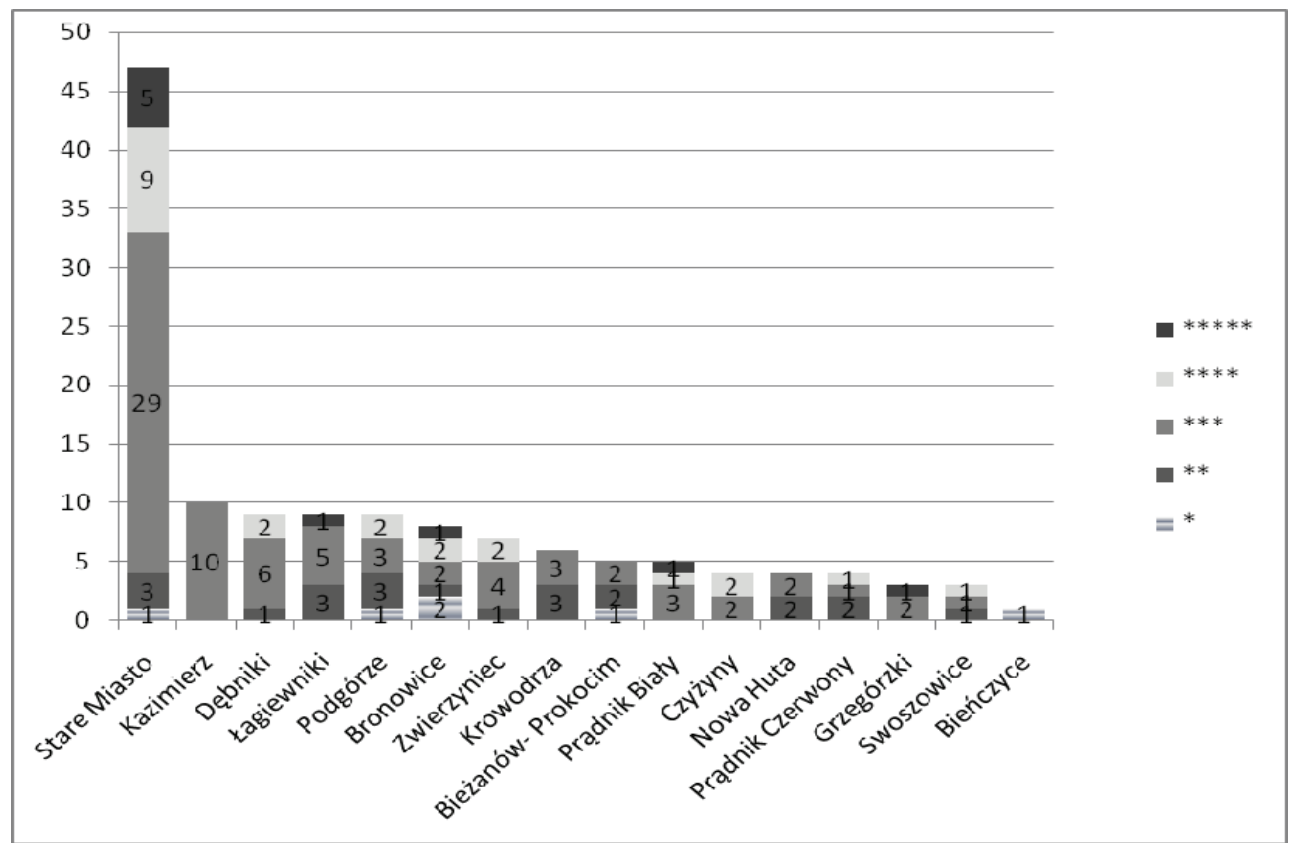

Ryc. 5. Hotele w krakowskich dzielnicach w roku 2009, w podziale na kategorie

Źródło: Opracowanie własne na podstawie danych z ewidencji obiektów hotelarskich. Internetowy serwis informacyjny Ministerstwa Sportu i Turystyki 


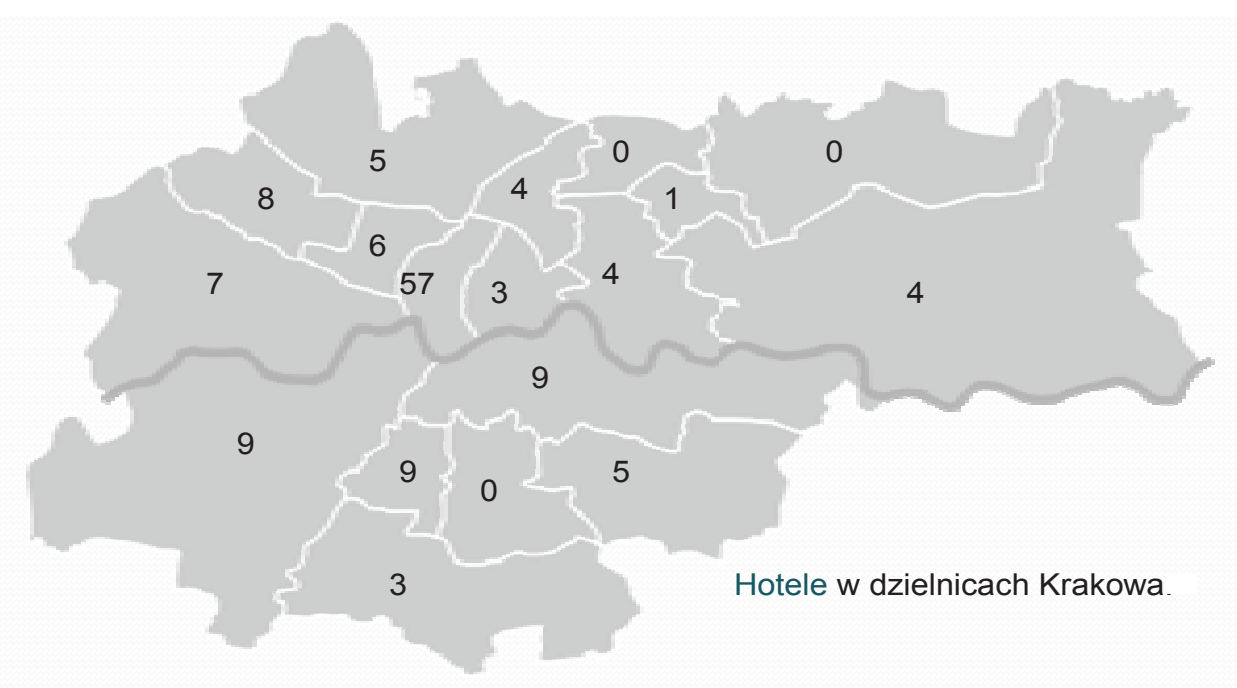

Ryc. 6. Koncentracja krakowskich hoteli w dzielnicach w roku 2009

Źródło: Opracowanie własne na podstawie danych z ewidencji obiektów hotelarskich. Internetowy serwis informacyjny Ministerstwa Sportu i Turystyki

\section{SieĆ HOTELOWA AGLOMERACJI KRAKOWSKIEJ}

W 2008 r. średnio w Polsce na $100 \mathrm{~km}^{2}$ przypadało 2,2 obiektu noclegowego. Wskaźniki przekraczające średnią krajową odnotowano w 6 województwach, przy czym najwyższe wartości osiagnęły one w województwie małopolskim - 5,7 obiektu na $100 \mathrm{~km}$. W $2008 \mathrm{r}$. stopień wykorzystania miejsc noclegowych osiagnął w woj. małopolskim 47,7\% ${ }^{7}$. Na tak dobry wynik województwa w dużej mierze wpływ ma aglomeracja krakowska.

Stanowiące układ funkcjonalny miasto Kraków i otaczające go gminy i powiaty są powiązane różnymi związkami interakcyjnymi. Obszar ten zajmuje powierzchnię $4069 \mathrm{~km}$ ، i jest zamieszkiwany przez 1,45 miliona ludzi. Stanowi to ogromy potencjał dla budowania bazy ekonomicznej związanej z usługami turystycznymi, a zwłaszcza z usługami hotelarskimi.

\section{Hotele gmin strefy podmiejskiej}

Leżące w bezpośrednim sąsiedztwie gminy podmiejskie są także miejscem inwestycji hotelarskich. Gmina Wieliczka, w której znajduje się 10 hoteli, jest liderem jeśli chodzi o liczbę hoteli. Na rozwój tego typu bazy w głównym stopniu wpłynęła kopalnia soli, która w zasadniczym stopniu decyduje o atrakcyjności Wieliczki. Na terenie gminy znajdują się dwa hotele czterogwiazdkowe, pięć trzygwiazdkowych i trzy dwugwiazdkowe.

\footnotetext{
${ }^{7}$ Informacje i opracowania statystyczne GUS, Warszawa 2009, s. 35
} 


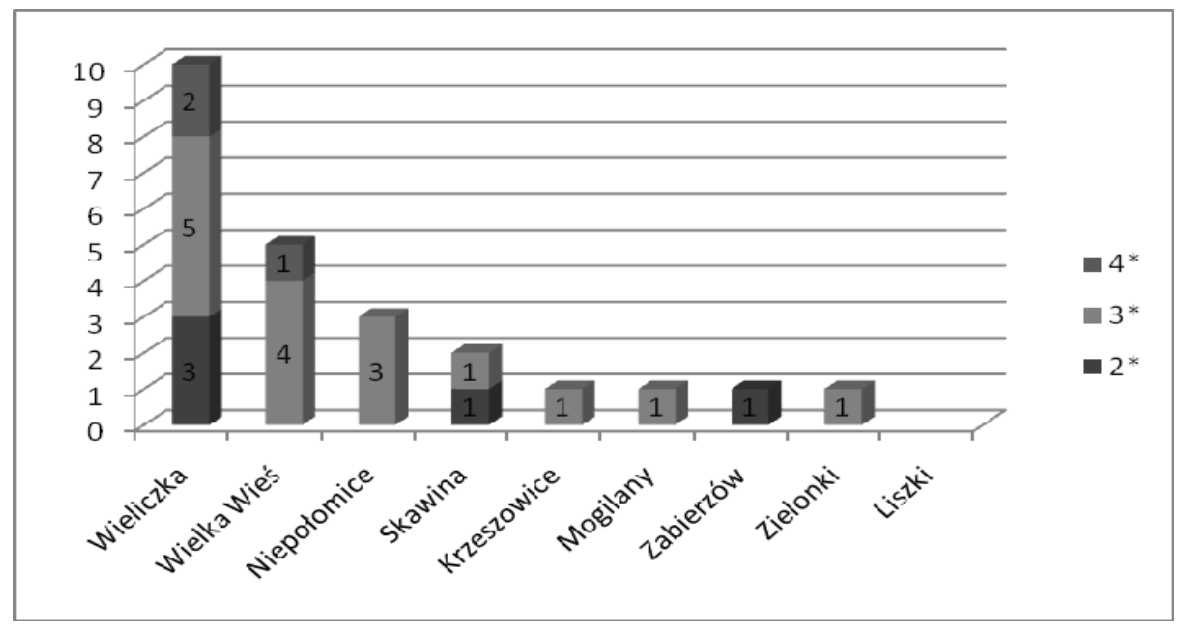

Ryc. 7. Hotele w podziale na kategorie, w gminach aglomeracji krakowskiej w roku 2009

Źródło: Opracowanie własne, na podstawie danych z ewidencji obiektów hotelarskich. Internetowy serwis informacyjny Ministerstwa Sportu i Turystyki

\section{Hotele w powiatach aglomeracji krakowskiej}

Największymi powiatami aglomeracji krakowskiej są powiaty: grodzki krakowski, wielicki i ziemski krakowski.

Miasta satelickie Krakowa połączone są z nim komunikacją autobusową oraz kolejową. W planach jest rozbudowa połączeń kolejowych, według projektu krakowskiej kolei miejskiej.

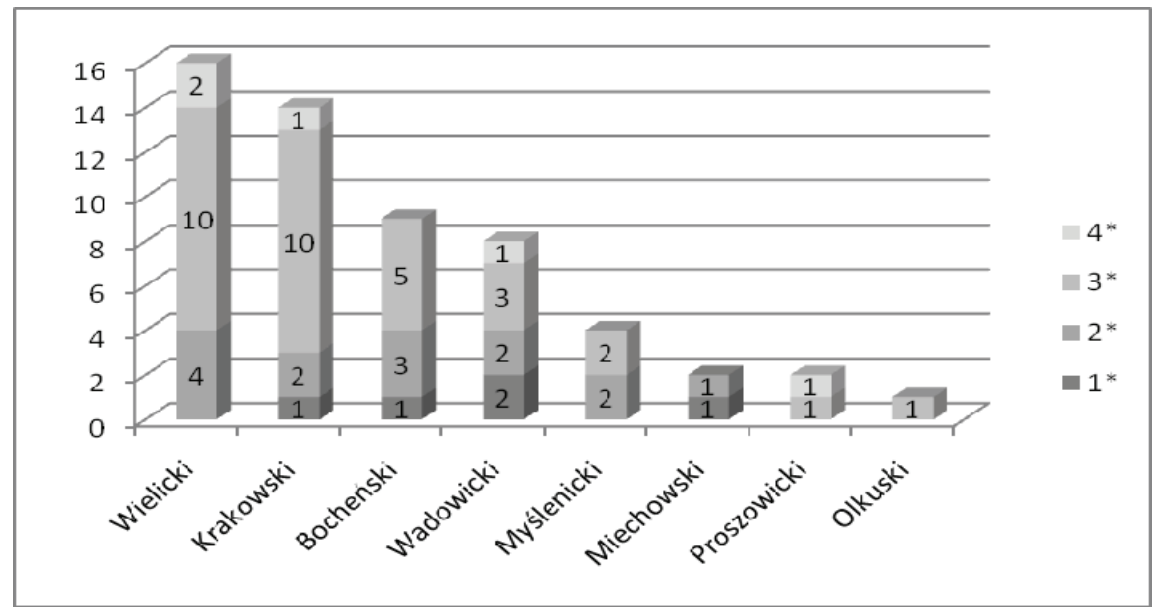

Ryc. 8. Hotele w powiatach aglomeracji krakowskiej w roku 2009

Źródło. Opracowanie własne, na podstawie danych z ewidencji obiektów hotelarskich. Internetowy serwis informacyjny Ministerstwa Sportu i Turystyki 
Nowo powstałe hotele w powiatach aglomeracji krakowskiej posiadają często rozbudowaną gastronomię, zaplecze konferencyjne lub centrum SPA. Jest to swoista „wartość dodana”, która wyróżnia ich ofertę i pozwala konkurować na rynku. Często w tych obiektach organizuje się wesela i inne imprezy okolicznościowe, zaspokajając lokalny popyt na tego typu usługi.

Warto wspomnieć o inwestycjach w obiekty zabytkowe, które zostały wyremontowane, a następnie dostosowane dla celów hotelarskich (Turówka w Wieliczce, Zamek Królewski w Niepołomicach). Dzięki przedsięwzięciom tego typu, realizowanym często na zasadach partnerstwa różnych podmiotów i z wykorzystaniem środków unijnych, zabytki są restaurowane i pełnią funkcje nie tylko hotelarskie, ale również reprezentacyjne.

\section{Podsumowanie}

Z przedstawionej analizy wynika, że najatrakcyjniejszą lokalizacją infrastruktury hotelowej aglomeracji jest Kraków. W dzielnicy Stare Miasto koncentruje się 47\% bazy hotelowej aglomeracji i jej strefy podmiejskiej. Stanowi to bardzo ważną przesłankę dla strategii rozwoju tego typu infrastruktury, która - należy wnosić - coraz bardziej zmieniać będzie bazę ekonomiczną poszczególnych dzielnic i ich zaplecza. Można domniemywać, iż w kolejnych latach rozwój sieci hotelowej będzie kontynuowany. Będzie to wymagało zmiany funkcji niektórych budynków, ich struktury własnościowej. Centrum miasta stawać się będzie w coraz większym stopniu przestrzenią usługową. Funkcje mieszkaniowe będą stopniowo zmniejszać swoje znaczenie w dzielnicy Stare Miasto.

Pozostałe lokalizacje w obrębie miasta i aglomeracji będą również miejscami inwestycji hotelowych. Brak ograniczeń występujących w zabytkowym centrum może stać się szansą na powstanie nowych obiektów, o większym potencjale i nowych funkcjach. Specjalizacja usług i nowa jakość produktu oferowanego poza miastem może stworzyć ciekawą alternatywę dla nabywców.

\section{Literatura}

Adamczewski J, 1992, Kraków od A do Z, Krajowa Agencja Wydawnicza, Kraków

Altkorn J., 2001, Marketing $w$ turystyce, PWN, Warszawa

Gaworecki W., 2007, Turystyka, PWE, Warszawa

Kuciński J., Trzciński Z., Zaborowski J., 2002, Podstawy prawne świadczenia ustug turystycznych, WSE, Warszawa

Kowalczyk A., 2001, Geografia turyzmu, PWN, Warszawa

Kowalczyk A., 2001, Geografia hotelarstwa, Wydawnictwo Uniwersytetu Łódzkiego, Łódź

Milewska M., Włodarczyk B., 2008, Hotelarstwo-podstawowe wiadomości, PWE, Warszawa

Raport o stanie miasta 2008, 2009, Urząd Miasta Krakowa, Wydział Strategii i Rozwoju Miasta, Kraków (dostępny na www.bip.kraków.pl)

Ruch turystyczny w Krakowie w 2008, 2008, raport końcowy - opracowany przez ekspertów Uniwersytetu Ekonomicznego w Krakowie, Akademii Wychowania Fizycznego w Krakowie, Wyższej Szkoły Turystyki i Ekologii w Suchej Beskidzkiej, kierownik projektu dr Krzysztof Borkowski, Małopolska Organizacja Turystyczna, Kraków (dostępny na www.mot.krakow.pl)

Turkowski M., 2003, Marketing ustug hotelarskich, PWE, Warszawa

Witkowski Cz., 2003, Międzynarodowe systemy hotelowe w Polsce, Wyższa Szkoła Ekonomiczna, Warszawa 


\section{Hotel network changes in Cracow agglomeration after WWII}

Hotel infrastructure belongs to the most important components of leading agglomerations economic base. It enables evolution of different types of tourist features, including business tourism.

Cracow belongs to leading national centres and is treated as the cultural capital of the country. As seen this way, all its functions should be continuously developed for strengthening its position in European and world scale. An important premise in the realization of the above objectives is hotel base quality, its organization, management and price competitiveness.

Changes of the economic system in Poland have created conditions for development of individual business, including tourism business. Progress of demonopolization and ownership transformations conditioned creation of private enterprises sector and privatization of state enterprises. Access to capital for private investors and its optimal utilization brought about emergence of independently operated hotel enterprises. Poland's openness and integration with the EU structures evoked foreign investor interest. International brands appeared on the market, hotels in their structures used capital, know-how and modern tools brought by hotel business leaders.

The present shape of Cracow agglomeration hotel network is the effect of many changes, equally of political, social, cultural and economic nature. The process, which has lasted for over 60 years, consisted of the post-war stagnation period, revival in the period of centrally planned economy (1970s and $80 \mathrm{~s}$ ), and dynamic development over the last two decades.

The presented analysis shows that the most attractive location for hotel infrastructure is the old city centre, with concentration of 58 objects, representing nearly $50 \%$ of agglomeration and suburban area hotels. It shows the importance of development strategy for this type of infrastructure, which may influence the economic base of the city, individual districts, areas and households.

Mgr Michał Malarz

Krakowska Akademia im. Andrzeja Frycza Modrzewskiego

e-mail: michal.malarz@gmail.com 